\title{
Product and service marketing workshop by using online marketplace in Durin Tonggal Village
}

\author{
Niskarto Zendrato $^{1 *}$, M.Andri Budiman ${ }^{1}$, Rossy Nurhasanah ${ }^{1}$, Ade Sarah Hufaizah ${ }^{1}$, \\ Fahrurrozi Lubis ${ }^{1}$ \\ ${ }^{1}$ Faculty of Computer Science and Information Technology, Universitas Sumatera Utara, \\ Medan, Indonesia \\ *Email: niskarto@gmail.com
}

\begin{abstract}
Durin Tonggal is one of the villages in Pancur Batu sub-district, Deli Serdang Regency, North Sumatra province, Indonesia. $60 \%$ of the people in Durin Tonggal Village work as entrepreneurs, especially small business entrepreneurs such as souvenir businesses, snack \& catering businesses, and so on. The activities of Pengabdian Kepada Masyarakat that have been carried out have focused on increasing understanding of the use of online media as a promotional tool for small business entrepreneurs in the Village of Durin Tonggal. With increasing public understanding, it can expand the buyers of products so that it will increase the sales of products and services. Increased sales transactions will result in high economic turnover so that this PKM activity is expected to improve the lives of Durin Tonggal villagers.
\end{abstract}

Keyword: Online Marketing, Marketplace

\begin{abstract}
Abstrak
Durin Tonggal merupakan salah satu desa yang ada di kecamatan Pancur Batu, Kabupaten Deli Serdang, provinsi Sumatra Utara, Indonesia. Masyarakat di Desa Durin Tonggal 60\%nya berprofesi sebagai pengusaha khususnya pelaku usaha UMKM seperti pelaku usaha souvenir, pelaku usaha snack \& catering, dan lain sebagainya. Kegiatan Pengabdian Kepada Masyarakat yang telah dilaksanakan ini fokus pada peningkatan pemahaman pemanfaatan media online sebagai sarana promosi bagi pelaku usaha UMKM di Desa Durin Tonggal. Dengan meningkatnya pemahaman masyarakat tersebut maka dapat memperluas pasar pembeli produk dan pengguna jasa pelaku usaha dan petani sehingga akan meningkatkan transaksi penjualan produk dan jasa. Transaksi penjualan yang meningkat akan mengakibatkan perputaran perekonomian yang tinggi sehingga dengan demikian kegiatan PKM ini diharapkan dapat meningkatkan taraf kehidupan masyarakat desa Durin Tonggal.
\end{abstract}

Kata Kunci : Promosi online, Marketplace

\section{PENDAHULUAN}

Durin Tonggal merupakan salah satu desa yang ada di kecamatan Pancur Batu, Kabupaten Deli Serdang, provinsi Sumatra Utara, Indonesia. Desa Durin Tonggal terdiri dari 5 dusun dengan jumlah penduduk 3461 jiwa dan 951 kepala keluarga, dengan mayoritas masyarakatnya berprofesi sebagai petani dan wiraswasta. Data mengenai profil Desa Durin Tonggal Kecamatan Pancurbatu dapat dilihat pada Tabel 1.1. 
Tabel 1.1. Jenis Pekerjaan dengan Jumlah Jiwa

\begin{tabular}{lr}
\hline \multicolumn{1}{c}{ Jenis Pekerjaan } & Jumlah Jiwa \\
\hline Pegawai Negeri & 39 orang \\
TNI & 5 orang \\
POLISI & 3 orang \\
Petani & 433 orang \\
Pedagang & 5 orang \\
Supir & 5 orang \\
Tukang Becak & 9 orang \\
Pengusaha & 45 orang \\
Pekerja Bangunan & 6 orang \\
Wiraswasta & 371 orang \\
Guru & 15 Orang \\
Perawat & 5 Orang \\
Karyawan Swasta & 81 Orang \\
\multicolumn{1}{c}{ Jumlah } & 1.022 Orang \\
\hline & \\
\hline &
\end{tabular}

Selain bertani dan berwiraswasta, sbagian masyarakat di Desa Durin Tonggal juga ada yang berprofesi sebagai pengusaha khususnya pelaku usaha UMKM seperti pelaku usaha kerajinan tangan, pelaku usaha souvenir, pelaku usaha bengkel, pelaku usaha snack dan catering, dan lain sebagainya. Terdapat juga pelaku usaha UMKM yang masih bersifat merintis kegiatan usaha namun ada pula pelaku usaha yang telah lama melakukan kegiatan usaha namun usahanya belum dapat berkembang dengan baik.

Beberapa permasalahan yang dapat digali berdasarkan survey tim pengabdian adalah banyak masyarakat pelaku usaha kesulitan untuk memasarkan produk maupun jasa karena keterbasan media promosi. Selain itu minat masyarakat di sana untuk memasarkan sendiri barang dagangan maupun jasa masih rendah, karena masayarakat Durin Tonggal menganggap bahwa pasar itu hanya kegiatan jual beli di suatu tempat atau titik yang disebut dengan pajak (pasar mingguan) dengan waktu yang terbatas hanya seminggu sekali dan juga membutuhkan modal usaha yang lebih besar untuk melakukan kegiatan berdagang sendiri hasil usaha karena harus menyewa toko. Selain itu pembeli juga terbatas hanya masyarakat di desa Durin Tonggal dan paling luas masyarakat kecamatan yang datang ke pasar tersebut untuk membeli kebutuhannya. Disini terlihat bahwa terbatasnya pasar penjualan, terbatasnya calon pembeli produk, serta terbatasnya waktu jual karena pasar hanya buka seminggu sekali. Keterbatasan tersebut mengakibatkan rendahnya transaksi jual dan beli yang mengakibatkan perputaran perekonomian di desa Durin Tonggal masih rendah.

Salah satu kegiatan warga dalam memproduksi kerajinan tangan dari bahan lidi dapat dilihat pada Gambar 1.1. 


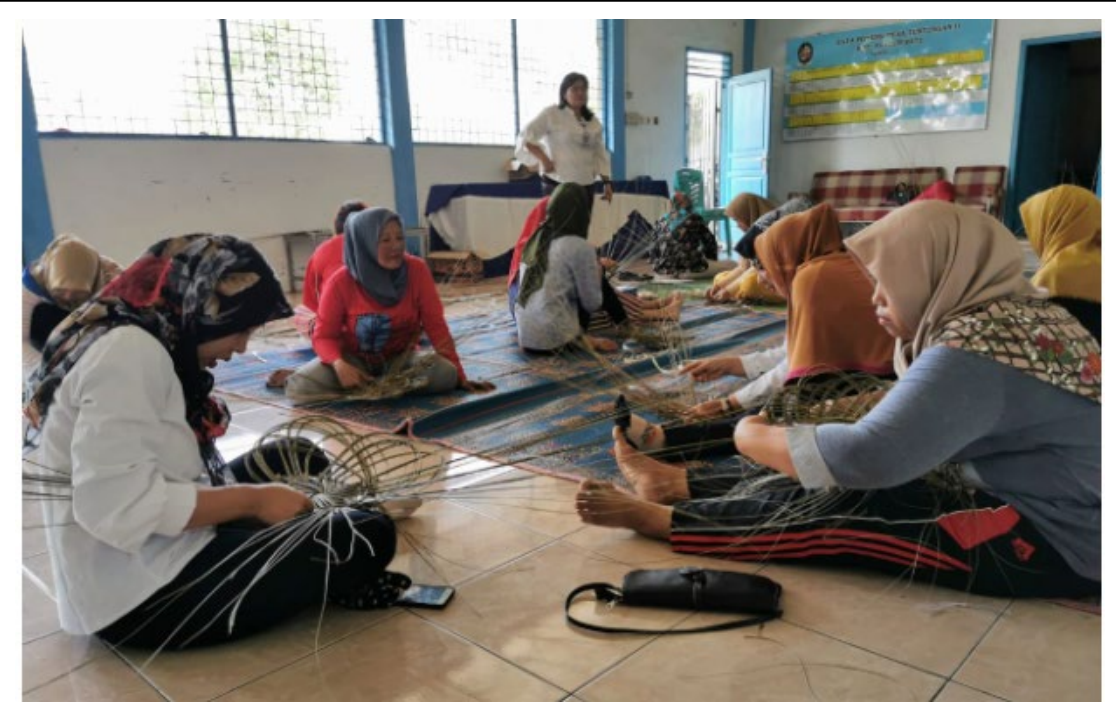

Gambar 1.1. Kegiatan warga memproduksi anyaman berbahan baku lidi di desa Durin Tonggal

Dari permasalahan warga tersebut, maka tim Pengabdian Kepada Masyarakat (PKM) menawarkan solusi untuk menggunakan media online untuk memperluas promosi produk dan jasa yang dijual oleh warga Dorin Tonggal, sehingga dapat menjangkau wilayah yang lebih luas. Sehingga diharapkan dapat meningkatkan kesejahteraan warga. Kegiatan PKM yang dilaksanakan di Desa Durin Tonggal berfokus pada peningkatan pemahaman dan keterampilan warga dalam memanfaatkan media online sebagai sarana promosi bagi pelaku usaha UMKM dan petani di Desa Durin Tonggal. Dengan meningkatnya pemahaman masyarakat tersebut maka dapat memperluas pasar pembeli produk dan pengguna jasa pelaku usaha dan petani sehingga akan meningkatkan transaksi penjualan produk dan jasa. Transaksi penjualan yang meningkat akan mengakibatkan perputaran perekonomian yang tinggi sehingga dengan demikian kegiatan PKM ini diharapkan dapat meningkatkan taraf kehidupan masyarakat desa Durin Tonggal.

\section{METODE PELAKSANAAN}

Kegiatan PKM ini dilaksanakan sejak bulan Mei sampai dengan November 2019. Metode pelaksanaan dalam menyelesaikan persoalan mitra yang telah disepakati bersama untuk dilakukan di Desa Durin Tonggal dapat dilihat pada bagan alir di Gambar 2.1 berikut 


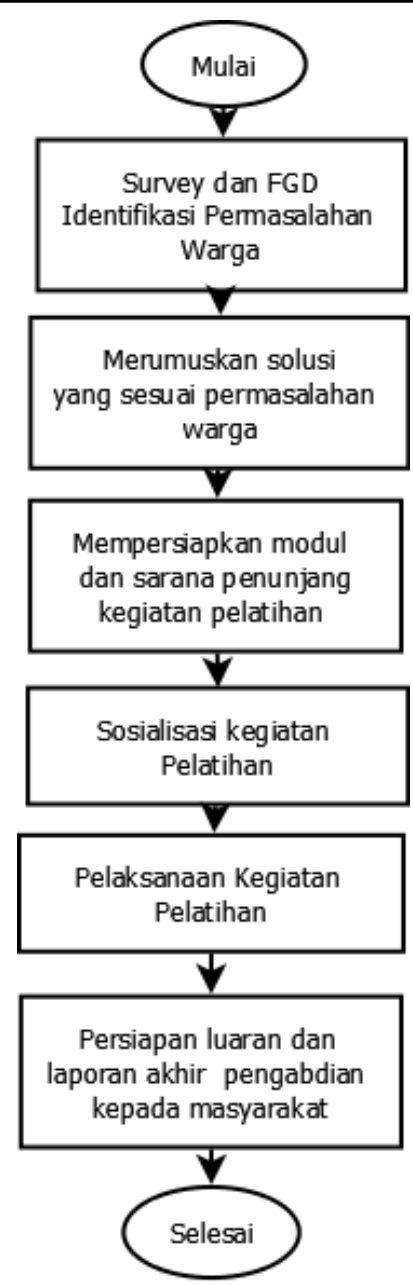

Gambar 2.1. Bagan Alir Metode Pelaksanaan Pengabdian Kepada Mayarakat

Sesuai bagan alir di atas, langkah-langkah kegiatan yang dilakukan dalam pelaksanaan kegiatan Pengabdian kepada Mayarakat di Desa Durin Tonggal adalah sebagai berikut.

a. Identifikasi permasalahan prioritas yang dihadapi oleh warga Desa Durin Tonggal menggunakan metode Forum Group Discussion (FGD). Dalam mengidentifikasi permasalahan yang ada di lokasi sasaran, tim pengusul menanyakan kepada warga Desa Durin Tonggal mengenai produk-produk yang dihasilkan warga desa, beserta hal-hal yang menjadi kendala dalam melakukan kegiatan UMKM. Dari diskusi tersebut didapatkan informasi bahwa terdapat berbagai produk yang dan jasa yang disediakan oleh warga, termasuk di antaranya adalah industri kreatif sebperti pengolahan lidi menjadi piring dan kerajinan tangan lainnya yang tentunya sangat berpotensi untuk dijual serta kendala keterbatasan dalam memasarkan produk tersebut.

b. Penawaran program pemasaran online yang diusulkan sebagai solusi atas persoalan yang dihadapi oleh warga desa. Tim PKM melakukan diskusi untuk membahas teknik penyelesaian masalah dengan pertimbangan keterbatasan biaya, waktu dan efektifitas metode yang digunakan. Dana yang diperoleh harus mampu menyediakan iptek yang akan menyelesaikan masalah di desa mitra.

c. Mempersiapkan modul dan sarana pendukung (seperti mikrotik dan hotspot) untuk mendukung kelancaran proses pelatihan. Tim PKM melakukan analisis ketersediaan sarana untuk mendukung kegiatan pelatihan pemasaran produk dan jasa secara online, seperti sumber daya listrik (resource device), sinyal komunikasi (media transmisi), device (HP/PC/Laptop), modem, aplikasi pendukung. Dalam hal ini dapat dipastikan bahwa 
seluruh bahan baku tersedia di lingkungan desa dan dapat digunakan untuk penyelesaian masalah.

d. Sosialisasi penggunaan iptek dalam rangka mendukung kegiatan usaha warga Desa Durin Tonggal. Sosialisasi ini diharapkan dapat diterima dan dilakukan warga desa untuk mendukung minat warga menjadi pengusaha UMKM yang berdaya saing.

e. Pelaksanaan pelatihan dan pedampingan kepada warga Desa Durin Tonggal dalam melakukan pemasaran online terhadap produk dan jasa yang dihasilkan warga.

f. Pemyusunan luaran dan laporan kegiatan

\section{HASIL DAN PEMBAHASAN}

Kegiatan pelatihan telah dilaksanakan pada hari jum'at, tanggal 10 Oktober 2019 di Kantor Kepala Desa Durin Tonggal. Kegiatan pelatihan pemanfaatan media online dalam memasarkan produk dan jasa ini dibuka langsung oleh Kepala Desa Durin Tonggal yang diikuti oleh 50 orang warga Durin Tonggal.

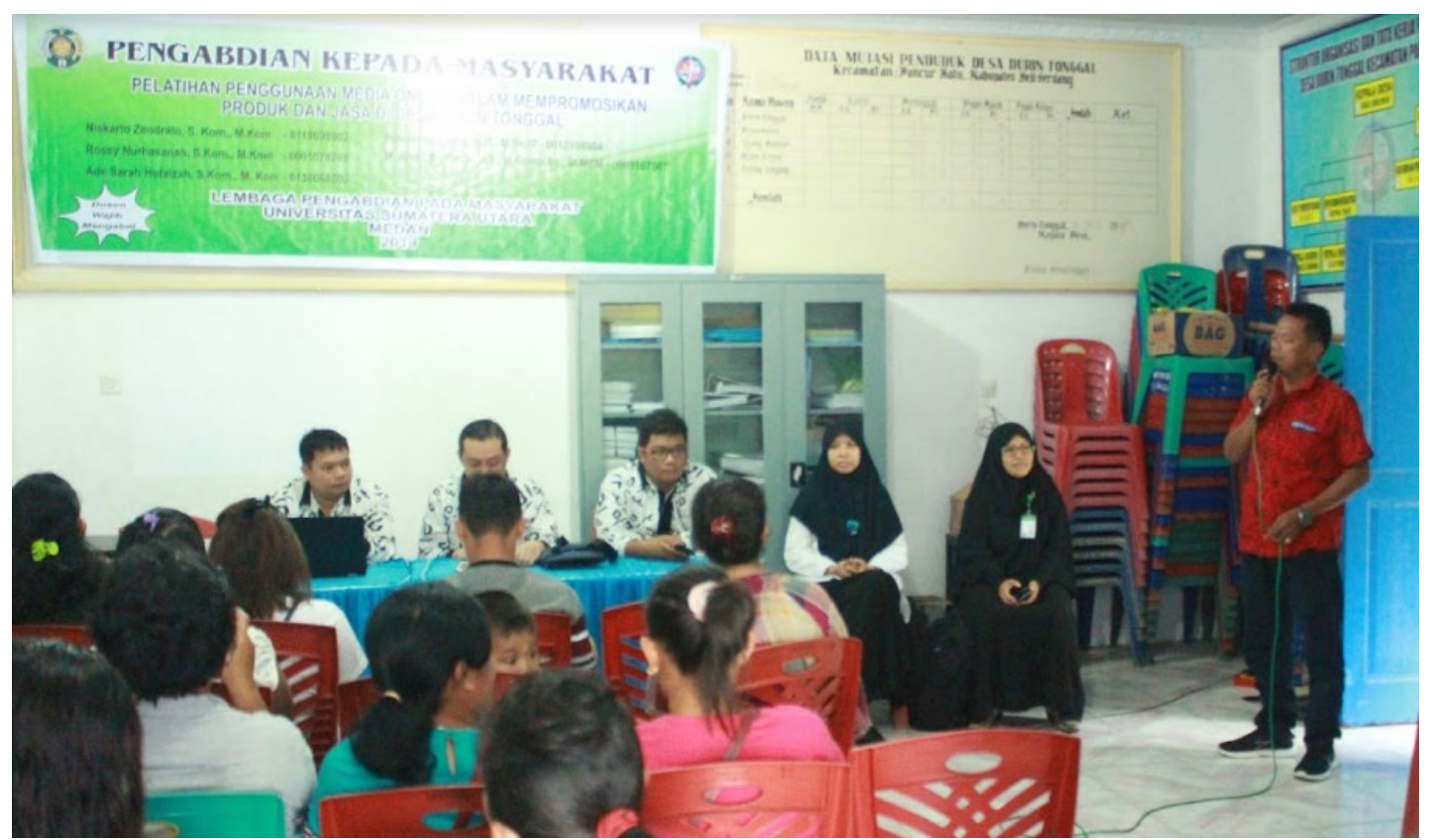

Gambar 3.1. Pelaksanaan Pengabdian kepada Masyarakat dibuka oleh Kepala Desa Durin Tonggal

Warga yang mengikuti kegiatan ini sebagian besar adalah pelaku usaha UMKM, dan sebagiannya lagi adalah ibu rumah tangga. Dalam kegiatan ini tim pengabdian juga melibatkan 3 orang mahasiswa dari Fakultas Ilmu Komputer dan Teknologi Informasi. Tujuannya adalah memberikan pengalaman bagi mahasiswa untuk terjun langsung ke tengah-tengah masyarakat, serta diharapkan akan tumbuh rasa kepedulian dan keinginan untuk berkontribusi nyata secara langsung pada masyarakat sesuai dengan kompetensi dan bidang keilmuan mahasiswa tersebut. Pada kegiatan ini, mahasiswa dilibatkan dalam membantu peserta melakukan instalasi dan pendaftaran akun Tokopedia. Seluruh peserta pelatihan ternyata belum pernah ada yang mencoba memanfaatkan marketplace dalam berjualan online, sehingga cukup memakan waktu dalam proses instalasi sampai dengan proses bertransaksi secara aman melalui marketplace Tokopedia. 


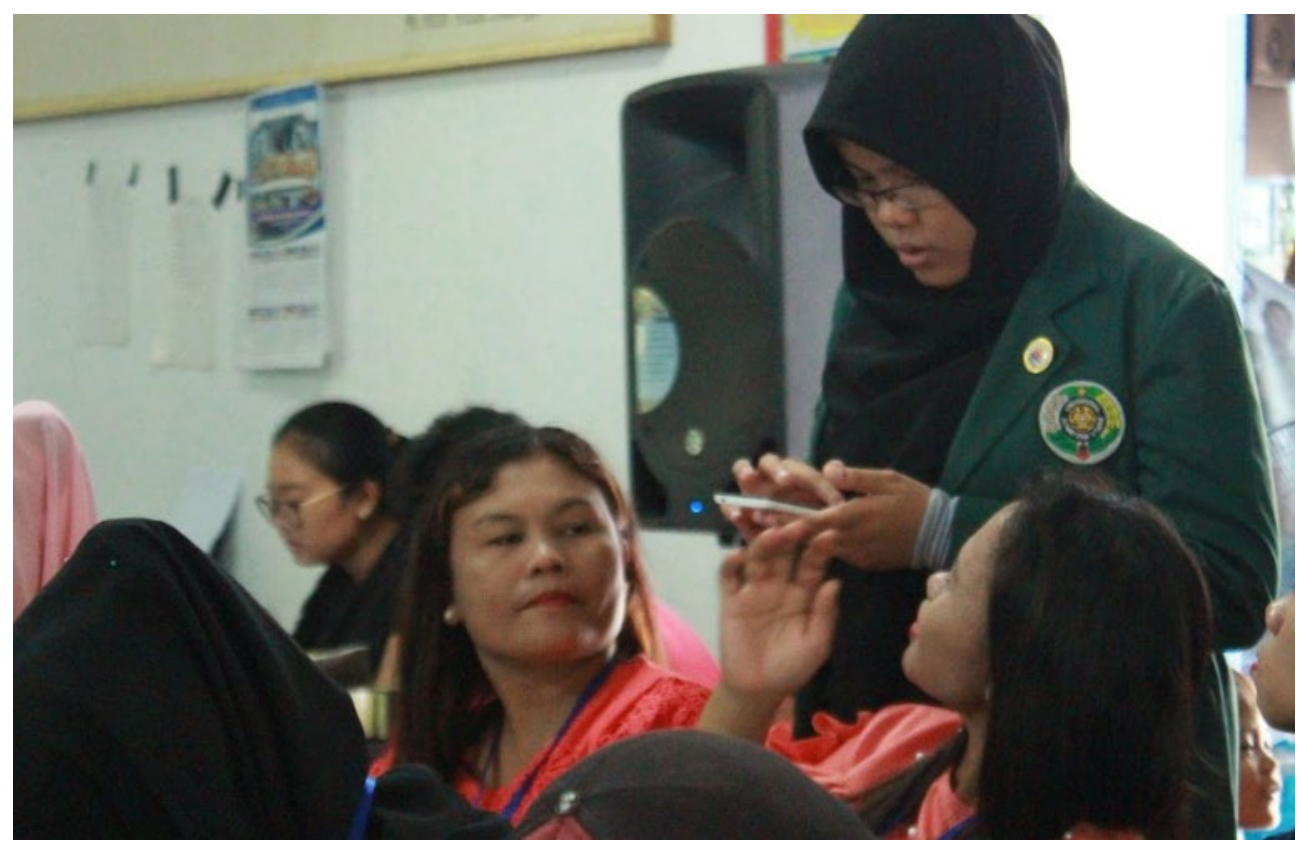

Gambar 3.2. Mahasiswa terlibat dalam kegiatan pengabdian kepada masyarakat

Untuk mendukung kegiatan ini, tim pengabdian menyediakan workshop kit berupa name tag, buku catatan, pulpen, hand out materi pelatihan, folder plastic dan kue kotak.

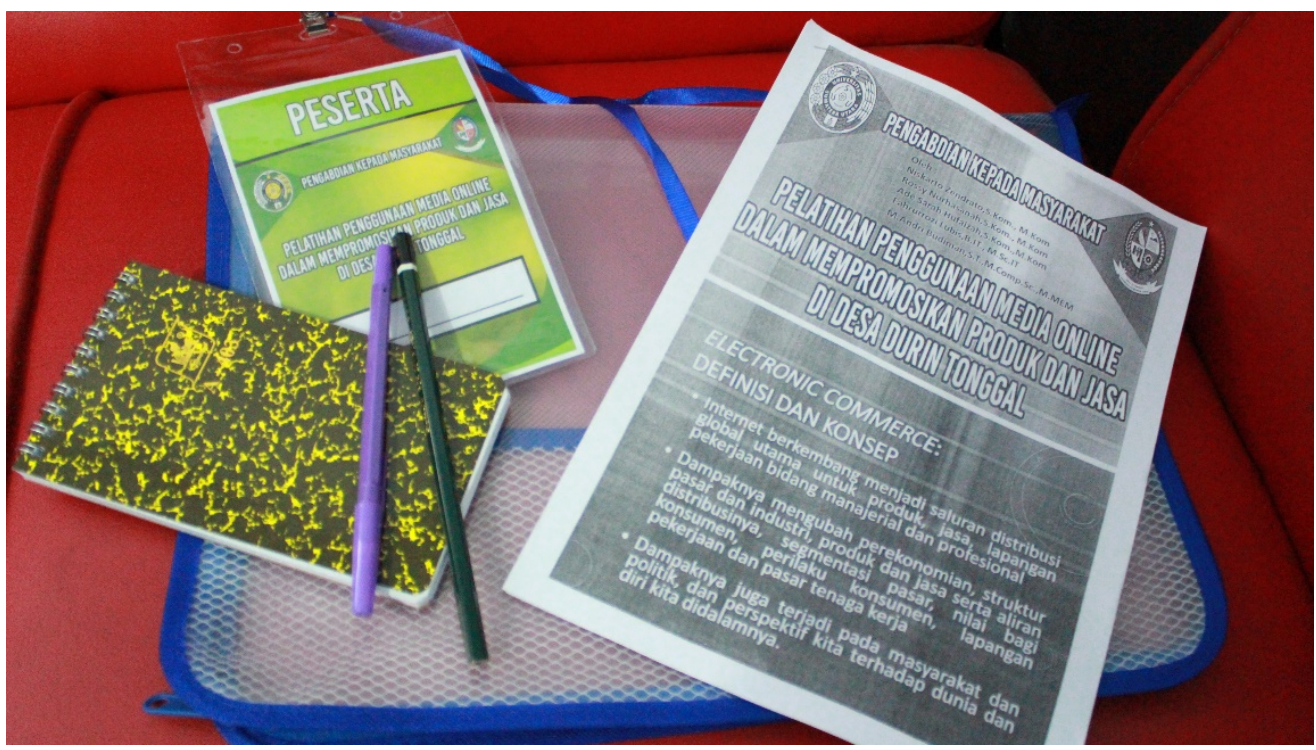

Gambar 3.3. workshop kit

Pada pelatihan ini disosialisasikan manfaat media online dalam melakukan pemasaran produk dan jasa. Kemudian diberi penjelasan kepada warga manfaat smartphone, bukan hanya untuk kegiatan bersosial media, namun juga dapat digunakan untuk menghasilkan uang. Kegiatan selanjutnya adalah melatih warga secara langsung tentang cara membuat dan mendaftarkan toko online mereka di Tokopedia, kemudian disampaikan cara untuk mengunggah foto produk dan mengatur parameter-parameter yang dibutuhkan. Selanjutnya masyarakat dipandu untuk melakukan transaksi jual beli secara aman dengan menggunakan aplikasi Tokopedia.

Pada pelatihan ini tim pengabdian juga menyampaikan jenis-jenis peluang usaha yang dapat mereka jalankan secara mudah dan tanpa biaya dengan menggunakan media online. Misalnya untuk penjualan pulsa, paket data, membuka gerai pembayaran BPJS, PLN, PDAM dan lainnya. 
Tim pengabdian sangat mengapresiasi warga Durin Tonggal yang sangat kooperatif dan antusias dalam mengikuti kegiatan ini. Hal ini dapat terlihat dari antusias peserta dalam bertanya dan mengikuti setiap langkah demi langkah yang diarahkan oleh tim pengabdian. Bahkan beberapa di antara peserta ada yang langsung menjalankan usahanya di akun Tokopedianya.

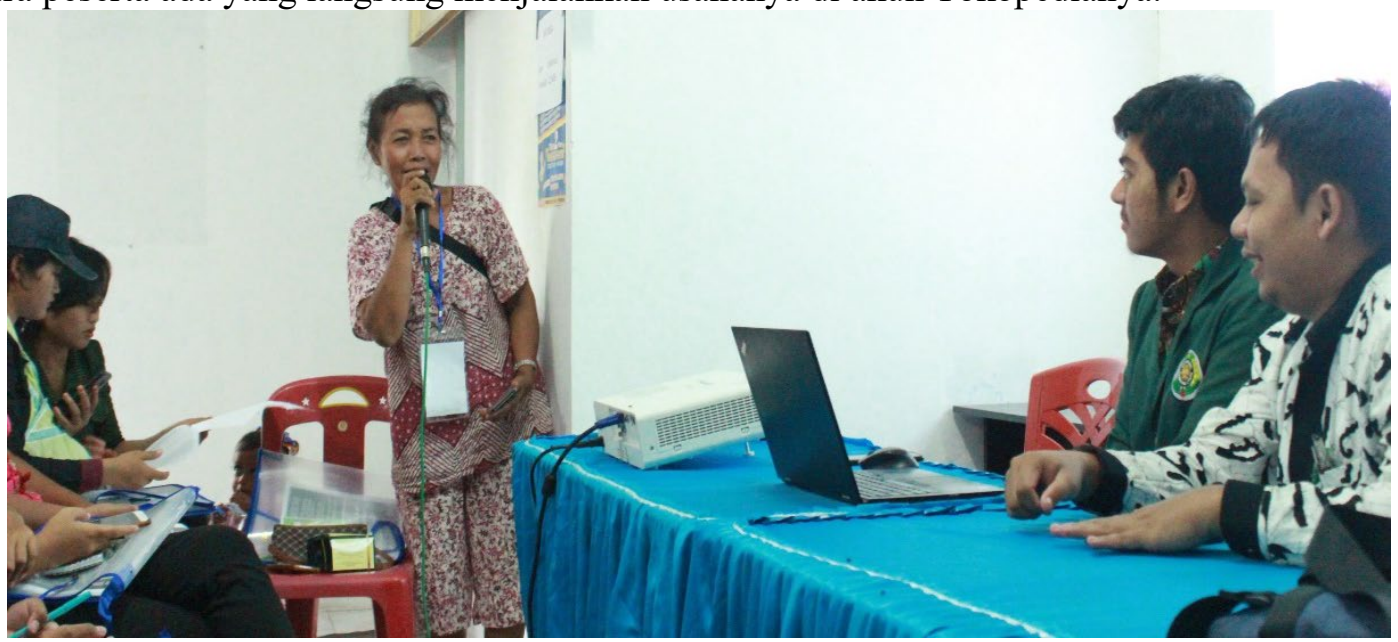

Gambar 3.4. Sesi diskusi pada saat Pelatihan.

Untuk mendukung warga desa dalam mengakses internet, tim pengabdian memberikan bantuan kepada warga Desa Durin Tonggal berupa 1 paket Hotspot (Mikrotik dan Modem 4G) beserta paket data 75GB (bukti serah terima terlampir). Dari pelatihan yang telah dilakukan, tim pengabdian selanjutnya memantau toko online yang telah berjalan dan tetap mendampingi warga desa jika menemukan masalah dan kedala dalam melakukan pemasaran produk-produknya secara online. Contoh toko online yang telah berjalan disajikan pada Gambar 3.5 berikut.

Home Kesehatan D Obat-Obatan Obat Herbal Minyak Obat Tradisional Karo
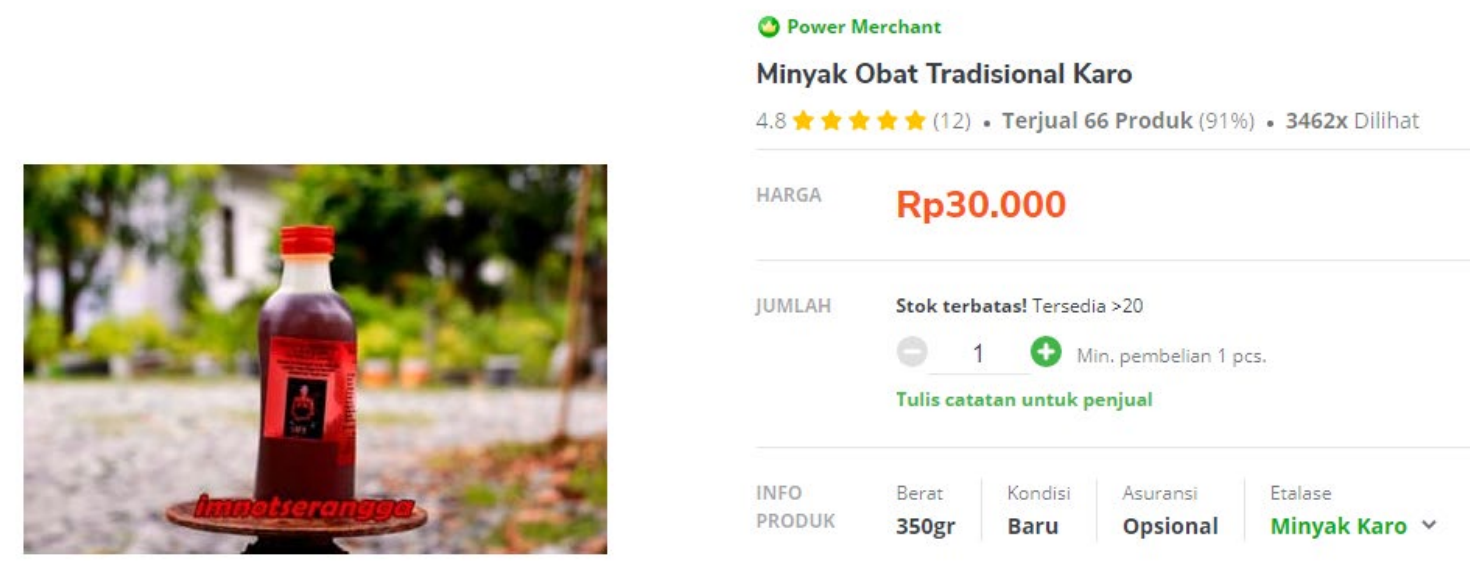

Gambar 3.5. Contoh toko Online warga yang menjual Minyak Karo.

\section{KESIMPULAN}

Berdasarkan hasil kegiatan pengabdian kepada masyarakat skim Dosen Wajib Mengabdi tahun 2019 yang telah dilaksanakan hingga bulan Oktober dapat diambil beberapa kesimpulan sebagai berikut:

1. Pelatihan penggunaan media online dalam mempromosikan produk dan jasa di Desa Durin Tonggal dapat membantu mitra dalam memasarkan berbagai produk khas lokal di Desa 
Durin Tonggal, seperti minyak karo, gula aren khas karo, produk kerajinan dari lidi, produk kesehatan.

2. Materi pelatihan dapat dipahami dengan baik dan langsung dijalankan dengan mudah oleh masyarkat. Hal ini dapat dilihat dari antusias warga setelah mendapatkan pelatihan, sebagian peserta langsung memanfaatkan Tokopedia untuk membuka toko online.

3. Pelatihan ini dapat membantu warga untuk mendapatkan penghasilan lebih tanpa modal, salah satunya dengan membuka Gerai Pembayaran yang melayani berbagai kebutuhan warga, seperti pembayaran iuran BPJS, pembayaran tagihan listrik dan PDAM, pengisian pulsa atau paket data, reservasi tiket kereta api dan pesawat dan lain sebagainya.

\section{UCAPAN TERIMAKASIH}

Kegiatan Pengabdian Kepada Masyarakat ini dapat teraksana berkat bantuan dana NON PNBP USU sesuai Kontrak Pelaksanaan Program Pengabdian Kepada Masyarakat Skim Dosen Mengabdi Tahun Anggaran 2019 dengan nomor kontrak 847/UN5.2.3.2.1/PPM/2019.

\section{DAFTAR PUSTAKA}

[BPS] Badan Pusat Statistik Kabupaten Deli Serdang. (2018). Kecamatan Pancurbatu dalam Angka.BPS Kabupaten Deli Serdang.Duphelia S. General Lobby Design and Development Game Programming Gems 4 Cengage Learning pp. 533-539

Profil Desa Durin Tonggal 2018 